\title{
Groundwater $\mathrm{N}_{2} \mathrm{O}$ emission factors of nitrate-contaminated aquifers as derived from denitrification progress and $\mathrm{N}_{2} \mathrm{O}$ accumulation
}

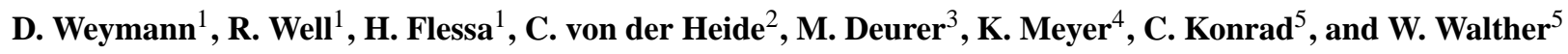 \\ ${ }^{1}$ Soil Science of Temperate and Boreal Ecosystems, Büsgen-Institute, University of Göttingen, Büsgenweg 2, \\ 37077 Göttingen, Germany \\ ${ }^{2}$ Institute for Soil Science, University of Hannover, Herrenhäuser Str. 2, 30419 Hannover, Germany \\ ${ }^{3}$ HortResearch, Tennent Drive, Palmerston North, 4474, New Zealand \\ ${ }^{4}$ Geries Ingenieure, Büro für Standorterkundung, Kirchberg 12, 37130 Gleichen, Germany \\ ${ }^{5}$ Institute for Groundwater Management, Dresden University of Technology, 01062 Dresden, Germany
}

Received: 12 February 2008 - Published in Biogeosciences Discuss.: 1 April 2008

Revised: 15 July 2008 - Accepted: 6 August 2008 - Published: 2 September 2008

\begin{abstract}
We investigated the dynamics of denitrification and nitrous oxide $\left(\mathrm{N}_{2} \mathrm{O}\right)$ accumulation in 4 nitrate $\left(\mathrm{NO}_{3}^{-}\right)$contaminated denitrifying sand and gravel aquifers of northern Germany (Fuhrberg, Sulingen, Thülsfelde and Göttingen) to quantify their potential $\mathrm{N}_{2} \mathrm{O}$ emission and to evaluate existing concepts of $\mathrm{N}_{2} \mathrm{O}$ emission factors. Excess $\mathrm{N}_{2}-\mathrm{N}_{2}$ produced by denitrification - was determined by using the argon (Ar) concentration in groundwater as a natural inert tracer, assuming that this noble gas functions as a stable component and does not change during denitrification. Furthermore, initial $\mathrm{NO}_{3}^{-}$concentrations $\left(\mathrm{NO}_{3}^{-}\right.$that enters the groundwater) were derived from excess $\mathrm{N}_{2}$ and actual $\mathrm{NO}_{3}^{-}$ concentrations in groundwater in order to determine potential indirect $\mathrm{N}_{2} \mathrm{O}$ emissions as a function of the $\mathrm{N}$ input. Median concentrations of $\mathrm{N}_{2} \mathrm{O}$ and excess $\mathrm{N}_{2}$ ranged from 3 to $89 \mu \mathrm{g} \mathrm{N} \mathrm{L}^{-1}$ and from 3 to $10 \mathrm{mg} \mathrm{N} \mathrm{L}^{-1}$, respectively. Reaction progress (RP) of denitrification was determined as the ratio between products $\left(\mathrm{N}_{2} \mathrm{O}-\mathrm{N}+\right.$ excess $\left.\mathrm{N}_{2}\right)$ and starting material (initial $\mathrm{NO}_{3}^{-}$concentration) of the process, characterizing the different stages of denitrification. $\mathrm{N}_{2} \mathrm{O}$ concentrations were lowest at RP close to 0 and RP close to 1 but relatively high at a RP between 0.2 and 0.6. For the first time, we report groundwater $\mathrm{N}_{2} \mathrm{O}$ emission factors consisting of the ratio between $\mathrm{N}_{2} \mathrm{O}-\mathrm{N}$ and initial $\mathrm{NO}_{3}^{-}-\mathrm{N}$ concentrations (EF1). In addition, we determined a groundwater emission factor (EF2) using a previous concept consisting of the ratio between $\mathrm{N}_{2} \mathrm{O}-\mathrm{N}$ and actual $\mathrm{NO}_{3}^{-}-\mathrm{N}$ concentrations. Depending on $\mathrm{RP}, \mathrm{EF}(1)$ resulted in smaller values compared to $\mathrm{EF}(2)$, demonstrating (i) the relevance of $\mathrm{NO}_{3}^{-}$
\end{abstract}

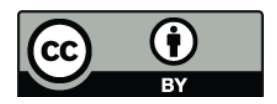

Correspondence to: $\mathrm{R}$. Well (rwell@gwdg.de) consumption and consequently (ii) the need to take initial $\mathrm{NO}_{3}^{-}-\mathrm{N}$ concentrations into account. In general, both evaluated emission factors were highly variable within and among the aquifers. The site medians ranged between 0.000430.00438 for $\mathrm{EF}(1)$ and $0.00092-0.01801$ for $\mathrm{EF}(2)$, respectively. For the aquifers of Fuhrberg and Sulingen, we found $\mathrm{EF}(1)$ median values which are close to the 2006 IPCC default value of 0.0025 . In contrast, we determined significant lower EF values for the aquifers of Thülsfelde and Göttingen. Summing the results up, our study supports the substantial downward revision of the IPCC default EF5-g from 0.015 (1997) to 0.0025 (2006).

\section{Introduction}

The trace gas nitrous oxide $\left(\mathrm{N}_{2} \mathrm{O}\right)$ is known to contribute to global warming (Duxbury and Mosier, 1993) and to the destruction of stratospheric ozone (Crutzen, 1981). A significant amount of $\mathrm{N}_{2} \mathrm{O}$ emissions originates from agricultural soils and aquatic systems (Mosier et al., 1998). In contrast to direct agricultural $\mathrm{N}_{2} \mathrm{O}$ emissions arising at the sites of agricultural production, e.g. soils, indirect emissions from ground and surface waters result from nitrogen leaching and runoff to adjacent systems (Well et al., 2005a; Nevison, 2000). The knowledge of these indirect emissions is limited because few studies have tried to relate subsurface $\mathrm{N}_{2} \mathrm{O}$ concentrations to $\mathrm{N}$ leaching from soils (Clough et al., 2005) and investigations of $\mathrm{N}_{2} \mathrm{O}$ in deeper aquifers are rare (Ronen et al., 1988; McMahon et al., 2000; Hiscock et al., 2002).

In the aquifers of unconsolidated pleistocene deposits covering large areas in the northern part of central Europe, agricultural $\mathrm{NO}_{3}^{-}$contamination often coincides with reducing

Published by Copernicus Publications on behalf of the European Geosciences Union. 
conditions (Walther, 1999), suggesting that this region might be susceptible for relatively high $\mathrm{N}_{2} \mathrm{O}$ fluxes from deeper groundwater. However, until now there have been no systematic investigations of $\mathrm{N}_{2} \mathrm{O}$ dynamics in these aquifers.

$\mathrm{N}_{2} \mathrm{O}$ emissions from groundwater were thought to comprise a significant fraction of total agricultural $\mathrm{N}_{2} \mathrm{O}$ emissions (IPCC, 1997), but recent studies show in agreement that their significance is lower (McMahon et al., 2000; Hiscock et al., 2003; Höll et al., 2005; Reay et al., 2005; Well et al., 2005a; Sawamoto et al., 2005). Consequently, the nitrous oxide emission factor from aquifers and agricultural drainage water (EF5-g) was corrected downwards from 0.015 to 0.0025 by the Intergovernmental Panel on Climate Change (IPCC) in 2006, taking the data of Hiscock et al. (2002, 2003), Reay et al. $(2004,2005)$ and Sawamoto et al. (2005) as a basis.

Typically, the $\mathrm{N}_{2} \mathrm{O}$ emission factor of a system is defined by the ratio between $\mathrm{N}_{2} \mathrm{O}$ emission and $\mathrm{N}$ input (IPCC, 1997). However, the IPCC factor characterizing indirect emissions from aquifers and agricultural drainage water had been derived from the ratio between dissolved $\mathrm{N}_{2} \mathrm{O}$ und $\mathrm{NO}_{3}^{-}$ concentrations observed in a small number of studies, because input and emission data had not been available. Consequently, there are uncertainties in the estimate of the EF5$\mathrm{g}$ because both $\mathrm{NO}_{3}^{-}$and $\mathrm{N}_{2} \mathrm{O}$ are subject to reaction during subsurface transport (Dobbie and Smith, 2003). Furthermore, determination of $\mathrm{N}_{2} \mathrm{O}$ fluxes from aquifers is connected with experimental difficulties: $\mathrm{N}_{2} \mathrm{O}$ as an intermediate product from denitrification is permanently influenced by different enzyme kinetics of various denitrifying communities and groundwater $\mathrm{N}_{2} \mathrm{O}$ concentration is the net result of simultaneous production and reduction reactions (Well et al., 2005b). Höll et al. (2005) stated that these transformations are the reason why $\mathrm{N}_{2} \mathrm{O}$ concentration in groundwater does not necessarily reflect actual indirect $\mathrm{N}_{2} \mathrm{O}$ emission.

$\mathrm{N}_{2} \mathrm{O}$ represents an obligate intermediate of the denitrification process. Denitrification is considered the most important reaction for nitrate $\left(\mathrm{NO}_{3}^{-}\right)$remediation in aquifers. This process occurs in $\mathrm{O}_{2}$ depleted layers with available electron donors (Ross, 1995; Böttcher et al., 1990). Especially in agricultural areas with high $\mathrm{N}$ inputs via fertilizers considerable $\mathrm{NO}_{3}^{-}$reduction is possible (Böttcher et al., 1985). Dinitrogen $\left(\mathrm{N}_{2}\right)$ is the final product of this process. Thus the quantification of groundwater $\mathrm{N}_{2}$ arising from denitrification (excess $\mathrm{N}_{2}$ ) can facilitate the reconstruction of historical $\mathrm{N}$ inputs, because $\mathrm{NO}_{3}^{-}$loss is derivable from the sum of denitrification products (Heaton, 1983; Böhlke and Denver, 1995). Generally, the concentration of excess $\mathrm{N}_{2}$ produced by denitrification in groundwater is estimated by comparing the measured concentrations of $\mathrm{Ar}$ and $\mathrm{N}_{2}$ with those expected from atmospheric equilibrium, assuming that the noble gas $\mathrm{Ar}$ is a stable component (Blicher-Mathiesen et al., 1998; Böhlke, 2002; Dunkle et al., 1993; Mookherji et al., 2003). However, measuring of excess $\mathrm{N}_{2}$ is complicated by variations of recharge temperatures and entrapment of air bubbles near the groundwater surface which leads to varying background concentrations of dissolved $\mathrm{N}_{2}$ in groundwater due to contact of the water with atmospheric air (Böhlke, 2002). Furthermore, $\mathrm{N}_{2}$ can be lost by degassing (Blicher-Mathiesen et al., 1998).

As a result of $\mathrm{NO}_{3}^{-}$consumption in denitrifying aquifers, the $\mathrm{NO}_{3}^{-}$concentration in the deeper groundwater is lower than the initial $\mathrm{NO}_{3}^{-}$concentration at the groundwater surface. Thus, the reconstruction of initial $\mathrm{NO}_{3}^{-}$concentrations by means of measuring excess $\mathrm{N}_{2}$ could be a tool to determine the $\mathrm{N}$ input to aquifers and thus reduce uncertainties connected with determination of EF5-g.

In this study, we measured excess $\mathrm{N}_{2}$ and $\mathrm{N}_{2} \mathrm{O}$ in the groundwater of 4 nitrate-contaminated, denitrifying aquifers in Northwest Germany in order (1) to estimate initial $\mathrm{NO}_{3}^{-}$ that enter the groundwater surface, (2) to assess potential indirect emissions of $\mathrm{N}_{2} \mathrm{O}$, and (3) to compare existing concepts of groundwater $\mathrm{N}_{2} \mathrm{O}$ emission factors.

\section{Material and methods}

\subsection{Study sites}

Investigations were conducted in the aquifers of 4 drinking water catchments (Fuhrberg, Göttingen, Thülsfelde and Sulingen) located in Northwest Germany, Lower Saxony. These aquifers consist of pleistocene sand and pleistocene gravel and are characterized by $\mathrm{NO}_{3}^{-}$contamination that results from intensive agricultural $\mathrm{N}$ inputs via fertilizers. In all aquifers, $\mathrm{NO}_{3}^{-}$concentrations in the deeper groundwater are substantially lower compared to the shallow groundwater. In previous studies, denitrification was identified as the natural process for reduction of groundwater $\mathrm{NO}_{3}^{-}$concentrations in Fuhrberg (Kölle et al., 1985; Böttcher et al., 1990), Thülsfelde (Pätsch, 2006; Walther et al., 2001), and Sulingen (Konrad, 2007). General properties of the aquifers are summarized in Table 1.

\subsection{Sampling and laboratory analyses}

Groundwater samples (3 or 4 replications per depth, respectively) were collected from groundwater monitoring wells allowing collection of samples from defined depths (Table 1). In Sulingen and Göttingen, we collected groundwater samples during a single sampling event, whereas up to three sampling events took place in Thülsfelde. In Fuhrberg, sampling was conducted 4 times within one year. The Fuhrberg site was equipped with multilevel sampling wells (Böttcher et al., 1985) with a depth resolution of $0.2 \mathrm{~m}$ in the first $2 \mathrm{~m}$ of the groundwater and $1.0 \mathrm{~m}$ for the rest. Samples were collected using a peristaltic pump (Masterflex, COLEPARMER, Vernon Hills, USA). Because negative pressure in the suction tubing might cause partial outgassing of the water sample during pumping, a low suction rate of approximately $50 \mathrm{ml} \mathrm{min}^{-1}$ was used to minimize this effect 
Table 1. General properties for the aquifers of Fuhrberg, Sulingen, Thülsfelde and Göttingen. Further information are available in Kölle et al. (1985), Böttcher et al. (1990), Pätsch (2006), Walther et al. (2001), Konrad (2007) and Schlie (1989).

\begin{tabular}{lllllll}
\hline $\begin{array}{l}\text { Site (number of samples/ } \\
\text { wells); [geographical } \\
\text { coordinates] }\end{array}$ & $\begin{array}{l}\text { Thickness of the aquifer } \\
\text { body/depth to the ground- } \\
\text { water table }[\mathrm{m}]\end{array}$ & $\begin{array}{l}\text { Hydraulic } \\
\text { active } \\
\text { sediment }\end{array}$ & $\begin{array}{l}\text { Sampling depth } \\
\text { (m below groundwater } \\
\text { surface) }\end{array}$ & $\mathrm{pH}$ & $\begin{array}{l}\mathrm{O}_{2} \\
{\left[\mathrm{mg} \mathrm{L}^{-1}\right]}\end{array}$ & $\begin{array}{l}\text { Temp } \\
{\left[{ }^{\circ} \mathrm{C}\right]}\end{array}$ \\
\hline $\begin{array}{l}\text { Fuhrberg }(80 / 7) \\
{\left[52^{\circ} 33^{\prime} \mathrm{N} ; 9^{\circ} 50^{\prime} \mathrm{E}\right]}\end{array}$ & $20-35 / 1-3$ & sand & $0.1-27.0$ & $3.7-6.6$ & $0-10.2$ & n.d. \\
$\begin{array}{l}\text { Sulingen }(30 / 2) \\
{\left[52^{\circ} 43^{\prime} \mathrm{N} ; 8^{\circ} 41^{\prime} \mathrm{E}\right]}\end{array}$ & $20-30 / 6-9$ & sand & $8.5-63.0$ & $4.6-6.7$ & $0.2-13.6$ & $10.3^{*}$ \\
$\begin{array}{l}\text { Thülsfelde }(19 / 4) \\
{\left[52^{\circ} 57^{\prime} \mathrm{N} ; 7^{\circ} 55^{\prime} \mathrm{E}\right]}\end{array}$ & $150 / 1-8$ & sand & $1.7-35.4$ & $4.3-5.8$ & $0.1-8.8$ & $10.1^{*}$ \\
$\begin{array}{l}\mathrm{Göttingen}(25 / 6) \\
{\left[51^{\circ} 30^{\prime} \mathrm{N} ; 9^{\circ} 56^{\prime} \mathrm{E}\right]}\end{array}$ & $5-10 / 1-2$ & gravel & $4.0-23.5$ & $6.8-7.9$ & $0.6-11.7$ & $9.8^{*}$ \\
\hline
\end{tabular}

n.d.: not determined; * median values; Temp: groundwater temperature.

(Blicher-Mathiesen et al., 1998). In Fuhrberg, additional samples from a continuously pumped groundwater stream were collected using taps at the pump outlets of drinking water wells which delivered raw water to the waterworks. The other sites were equipped with regular monitoring wells consisting of PVC-pipes (diameter between $3.81 \mathrm{~cm}$ and $10.16 \mathrm{~cm}$ ) with filter elements of one or two m length. In these wells, samples were collected with a submersible pump (GRUNDFOS MP1, Bjerringbro, Denmark), which prevents outgassing because the water samples are at a positive pressure during pumping. From one of these monitoring wells, replicate groundwater samples were collected from $0.5-2.5 \mathrm{~m}$ below the groundwater table using both pump types in order to estimate potential outgassing using the peristaltic pump. Differences between the treatments were non-significant, which implies that outgassing was negligible. For both pump types, groundwater was collected from the outlet through a $4 \mathrm{~mm}$ ID PVC tubing by placing its end to the bottom of $115 \mathrm{~mL}$ serum bottles. After an overflow of at least $115 \mathrm{ml}$ groundwater, the tubing was carefully removed and the bottles were immediately sealed with grey butyl rubber septa (ALTMANN, Holzkirchen, Germany) and aluminium crimp caps. There were no visible air bubbles in the tubings and the vial during the procedure. The samples were stored at $10^{\circ} \mathrm{C}$ (approximate groundwater temperature as estimated from mean annual air temperature) and analyzed within one week. Eight $\mathrm{mL}$ of helium were injected in each vial in order to replace an equivalent amount of groundwater and to create a gas headspace. Liquid and gas phase were equilibrated at constant temperature $\left(25^{\circ} \mathrm{C}\right)$ by agitating on a horizontal shaker for $3 \mathrm{~h}$. To analyse $\mathrm{N}_{2}$ and Ar, $1 \mathrm{~mL}$ headspace gas was injected manually with a gas-tight 1-mL syringe equipped with a valve (SGE, Darmstadt) into a gas chromatograph (Fractovap 400, CARLO ERBA, Milano) equipped with a thermal conductivity detector and a packed column (1.8 m length, 4 mm ID, molecular sieve $5 \AA$ ) and us- ing helium as carrier gas. Because retention times of $\mathrm{O}_{2}$ and $\mathrm{Ar}$ are similar on this column, $\mathrm{O}_{2}$ was completely removed using a heated $\mathrm{Cu}$-column $\left(800^{\circ} \mathrm{C}\right)$ which was installed prior to the GC-column. To avoid contamination with atmospheric air during sample injection the following precautions were necessary: the syringe was flushed with helium immediately before penetrating the sample septum. Subsequently, the syringe was "over-filled" by approximately $15 \%$, the syringe valve closed and the plunger adjusted to $1 \mathrm{~mL}$ in order to slightly pressurize the sample. The syringe needle was then held directly above the injection port before the valve was opened for a second to release excess pressure and the sample was finally injected. Generally, 3 replicate groundwater samples were analysed. A fourth sample served as reserve in case of failure during analysis. A calibration curve was obtained by injecting $0.2,0.3,0.5$ and $1.0 \mathrm{~mL}$ of atmospheric air (3 replications each), resulting in different $\mathrm{Ar}$ and $\mathrm{N}_{2}$ concentrations per calibration step.

To determine dissolved $\mathrm{N}_{2} \mathrm{O}$ and $\mathrm{CO}_{2}$ concentrations, the headspace volume was augmented to $40 \mathrm{~mL}$ by an additional injection of $32 \mathrm{~mL}$ of helium and an equivalent amount of groundwater was replaced. After equilibrating liquid and gas phase at constant temperature $\left(25^{\circ} \mathrm{C}\right), 24 \mathrm{~mL}$ of the headspace gas were equally distributed to 2 evacuated septum-capped exetainers ${ }^{\circledR}$ (12 mL, Labco, Wycombe, UK). $\mathrm{N}_{2} \mathrm{O}$ and $\mathrm{CO}_{2}$ were analyzed using a gas chromatographer equipped with a thermal conductivity detector (Fractovap 400, CARLO ERBA, Milano), with an electron capture detector and an autosampler as described by Well et al. (2003). $\mathrm{NO}_{3}^{-}$concentration was determined on $0.45 \mu \mathrm{m}$ membranefiltered samples by use of an ion chromatograph (ICS-90, DIONEX, Idstein, Germany) equipped with an IC-AIS column.

Molar fractions of $\mathrm{N}_{2}, \mathrm{Ar}, \mathrm{CO}_{2}$ and $\mathrm{N}_{2} \mathrm{O}$ in the headspace of sample vials and the volume of added helium as well as the solubilities of these gases (Weiss, 1970, 1971; Weiss and 
Price, 1980) were used to calculate partial pressure and molar fraction in the groundwater for each gas (Blicher-Mathiesen et al., 1998). Total pressure in the headspace after equilibration was obtained from the sum of partial pressures of each gas or by direct measurement using a pressure transducer equipped with a hypodermic needle (Thies Klima, Göttingen, Germany) were in good agreement, i.e. differences between measured and calculated pressure were $<9 \%$. We checked the accuracy of estimated molar concentrations of dissolved gases from headspace concentration by adding defined volumes of $\mathrm{N}_{2}$ ( 1 and $2 \mathrm{~mL}$, respectively) to samples of demineralised water equilibrated at $10^{\circ} \mathrm{C}$. Recovery of $\mathrm{N}_{2}$ was found to be satisfactory and was $92.91 \%$ for 1 and $2 \mathrm{~mL}$ added $\mathrm{N}_{2}$.

\subsection{Calculation of excess $\mathrm{N}_{2}$}

$\mathrm{N}_{2}$ dissolved in groundwater samples includes atmospheric $\mathrm{N}_{2}$ and $\mathrm{N}_{2}$ from denitrification (excess $\mathrm{N}_{2}$ ) accumulated during the groundwater flow path (Böhlke, 2002). $\mathrm{N}_{2}$ from denitrification can be determined by subtracting atmospheric $\mathrm{N}_{2}$ from total $\mathrm{N}_{2}\left(\mathrm{~N}_{2} \mathrm{~T}\right)$. Atmospheric $\mathrm{N}_{2}$ in groundwater consists of two components, (i) $\mathrm{N}_{2}$ dissolved according to equilibrium solubility $\left(\mathrm{N}_{2} \mathrm{EQ}\right)$, and (ii) $\mathrm{N}_{2}$ from "excess air" $\left(\mathrm{N}_{2 \mathrm{EA}}\right.$, Heaton and Vogel, 1981). Excess air denotes dissolved gas components in excess of equilibrium and other known subsurface gas sources. Excess air originates from entrapment of air bubbles near the groundwater table during recharge which is subject to complete or partial dissolution (Holocher et al., 2002).

Excess $\mathrm{N}_{2}\left(X_{\text {excess } \mathrm{N}_{2}}\right)$ can thus be calculated using the following equation:

$X_{\text {excess } \mathrm{N}_{2}}=X_{\mathrm{N}_{2} \mathrm{~T}}-X_{\mathrm{N}_{2} \mathrm{EA}}-X_{\mathrm{N}_{2} \mathrm{EQ}}$

where $X$ denotes molar concentration of the parameters. $X_{\mathrm{N}_{2} \mathrm{~T}}$ represents the molar concentration of the total dissolved $\mathrm{N}_{2}$ in the groundwater sample. $X_{\mathrm{N}_{2} \mathrm{EQ}}$ is the molar concentration of dissolved $\mathrm{N}_{2}$ in equilibrium with the atmospheric concentration. It depends on the water temperature during equilibration with the atmosphere, i.e. the temperature at the interface between the unsaturated zone and the groundwater surface. For the equilibrium temperature we assumed a constant value of $10^{\circ} \mathrm{C}$ which was close to mean groundwater temperature. This is also similar to the mean annual temperature which is the best estimate of the mean temperature at the interface between unsaturated zone and the aquifer (Heaton and Vogel, 1981). $X_{\mathrm{N}_{2} \text { EQ }}$ was thus obtained using $\mathrm{N}_{2}$ solubility data (Weiss, 1970) for this recharge temperature. $\mathrm{N}_{2 \mathrm{EA}}$ represents $\mathrm{N}_{2}$ from excess air. For a given recharge temperature, excess air is reflected by noble gas concentrations (Holocher et al., 2002). If excess air results from complete dissolution of gas bubbles, the gas composition of the excess air component is identical to atmospheric air (Heaton et al., 1983; Aeschbach-Hertig et al., 2002). For this case, $X_{\mathrm{N}_{2}}$ EA can be calculated from the concentration of only one noble gas, e.g. Argon (Heaton and Vogel, 1981):

$X_{\mathrm{N}_{2} \text { EA }}=\left(X_{\mathrm{ArT}}-X_{\mathrm{ArEQ}}\right) * \frac{X_{\mathrm{N}_{2} \text { atm }}}{X_{\mathrm{Ar} \mathrm{atm}}}$

where $X_{\mathrm{N}_{2} \text { atm }}$ and $X_{\mathrm{Ar} \text { atm }}$ denote atmospheric mole fractions of $\mathrm{N}_{2}$ and Ar, respectively. $X_{\mathrm{ArT}}$ represents the molar concentration of the total dissolved Ar in the groundwater sample. $X_{\mathrm{ArEQ}}$ is the molar concentration of dissolved Ar in equilibrium with the atmospheric concentration.

If excess air originates from incomplete dissolution of entrapped gas bubbles, then the $\mathrm{N}_{2}$-to-Ar ratio of excess air is lower than the atmospheric $\mathrm{N}_{2}$-to-Ar ratio due to fractionation (Holocher et al., 2002). The lowest value of the $\mathrm{N}_{2}$-to- $\mathrm{Ar}$ ratio of excess air is equal to the $\mathrm{N}_{2}$-to-Ar ratio in water at atmospheric equilibrium (Aeschbach-Hertig et al., 2002) since this lowest value is approximated when the dissolution of entrapped air approaches zero. The lowest estimate of $X_{\mathrm{N}_{2}}$ EA is thus given by

$X_{\mathrm{N}_{2} \mathrm{EA}}=\left(X_{\mathrm{ArT}}-X_{\mathrm{ArEQ}}\right) * \frac{X_{\mathrm{N}_{2} \mathrm{EQ}}}{X_{\mathrm{ArEQ}}}$

where $X_{\mathrm{N}_{2} \mathrm{EQ}}$ and $X_{\mathrm{ArEQ}}$ denote equilibrium mole fractions of $\mathrm{N}_{2}$ and Ar, respectively. The actual fractionation of excess air can only be determined by analysing several noble gases (Aeschbach-Hertig et al., 2002). Because we measured only Ar, our estimate of excess $\mathrm{N}_{2}$ includes an uncertainty from the unknown $\mathrm{N}_{2}$-to-Ar ratio of the excess air component. This uncertainty $(U)$ is equal to the difference between $\mathrm{N}_{2 E A}$ calculated with Eqs. (2) and (3), and is thus given by

$U_{\mathrm{N}_{2} \mathrm{EA}}=\left(X_{\mathrm{ArT}}-X_{\mathrm{ArEQ}}\right) *\left(X_{\mathrm{N}_{2} \mathrm{~atm}} / X_{\mathrm{Aratm}}-X_{\mathrm{N}_{2} \mathrm{EQ}} / X_{\mathrm{ArEQ}}\right)$

It can be seen that $U_{\mathrm{N}_{2} \mathrm{EA}}$ directly depends on excess $\mathrm{Ar}$, i.e., $X_{\mathrm{ArT}}-X_{\mathrm{ArEQ}}$. We used equations 1 to 3 to calculate lowest and upper estimates of excess air and excess $\mathrm{N}_{2}$ and to assess the remaining uncertainty of our excess $\mathrm{N}_{2}$ estimates connected with excess air fractionation. Finally, we calculated means from the lowest and upper estimates which we considered as best estimates of excess $\mathrm{N}_{2}$.

\subsection{Standard deviation and repeatability of excess $\mathrm{N}_{2}$ anal- ysis}

Precision of the method was tested by evaluating standard deviation $(\sigma)$ and repeatability $(R)$. $\sigma$ was determined for $\mathrm{N}_{2}$ and $\mathrm{Ar}$ concentrations in atmospheric air samples $(n=20)$, giving $0.000069 \mathrm{LL}^{-1}$ for $\mathrm{Ar}$ and $0.006449 \mathrm{LL}^{-1}$ for $\mathrm{N}_{2}$, respectively. Repeatability $(R)$ was derived from $R=2 \sqrt{2} \sigma$, giving $0.000196 \mathrm{LL}^{-1}$ for $c \operatorname{Ar}\left(R_{\mathrm{Ar}}\right)$ and $0.018241 \mathrm{LL}^{-1}$ for $c \mathrm{~N}_{2}\left(R_{\mathrm{N}_{2}}\right)$. Errors resulting from $R_{\mathrm{N}_{2}}$ and $R_{\mathrm{Ar}}$ were obtained using Eqs. (1)-(3), giving 1.59 and $2.05 \mathrm{mg} \mathrm{N} \mathrm{L}^{-1}$, respectively. Finally, total error for excess $\mathrm{N}_{2}$ was determined by Gaussian error propagation (Mölders et al., 2005) giving $2.58 \mathrm{mg} \mathrm{N} \mathrm{L}^{-1}$ for excess $\mathrm{N}_{2}$. 
Table 2. Excess $\mathrm{N}_{2}, \mathrm{~N}_{2} \mathrm{O}, \mathrm{NO}_{3}^{-}$, and $\mathrm{NO}_{3 t 0}^{-}$concentrations and reaction progress of denitrification (RP) of the investigated aquifers. $\mathrm{NO}_{3 t 0}^{-}$ concentrations were calculated using eqation 5, RP was calculated using Eq. (6).

\begin{tabular}{lcrrrrr}
\hline site & & $\begin{array}{r}\text { excess N } \\
{\left[\mathrm{mg} \mathrm{N} \mathrm{L}^{-1}\right]}\end{array}$ & $\begin{array}{r}\mathrm{N}_{2} \mathrm{O} \\
{\left[\mu \mathrm{g} \mathrm{N}^{-1}\right]}\end{array}$ & $\begin{array}{r}\mathrm{NO}_{3}^{-} \\
{\left[\mathrm{mg} \mathrm{N} \mathrm{L}^{-1}\right]}\end{array}$ & $\begin{array}{r}\mathrm{NO}_{3}^{-} \\
{\left[\mathrm{mg} \mathrm{N}^{-1}\right]}\end{array}$ & $\mathrm{RP}$ \\
\hline \multirow{5}{*}{ Fuhrberg } & Min & 0.13 & 0.19 & 0.00 & 3.14 & 0.05 \\
& Max & 13.14 & 1271.39 & 41.67 & 44.75 & 1.00 \\
& Median & 4.20 & 89.00 & 8.51 & 13.14 & 0.45 \\
Thülingen & Min & -0.90 & 0.53 & 0.00 & 0.22 & 0.00 \\
& Max & 14.85 & 254.51 & 37.12 & 51.04 & 1.00 \\
& Median & 2.08 & 8.27 & 9.26 & 13.16 & 0.33 \\
Göttingen & Min & 0.57 & 0.16 & 0.23 & 1.48 & 0.00 \\
& Max & 28.83 & 180.86 & 33.18 & 40.87 & 0.99 \\
& Median & 7.97 & 18.39 & 4.89 & 17.11 & 0.68 \\
& Min & 1.61 & 0.07 & 0.45 & 2.05 & 0.11 \\
& Max & 10.71 & 18.68 & 12.64 & 13.93 & 0.96 \\
& Median & 3.19 & 3.40 & 3.84 & 8.24 & 0.43 \\
\hline
\end{tabular}

2.5 Initial $\mathrm{NO}_{3}^{-}$concentration, reaction progress and emission factors

Intial $\mathrm{NO}_{3}^{-}$concentration $\left(c \mathrm{NO}_{3 t 0}^{-}\right)$at a given location on the aquifer surface is defined by the $\mathrm{NO}_{3}^{-}$concentration of the recharging water before alteration by denitrification in groundwater (Heaton et al., 1983).

From the assumption that $\mathrm{NO}_{3}^{-}$consumption on the groundwater flow path between the aquifer surface and a given sampling spot originates from denitrification and results in quantitative accumulation of gaseous denitrification products $\left(\mathrm{N}_{2} \mathrm{O}\right.$ and $\left.\mathrm{N}_{2}\right)$, it follows that $c \mathrm{NO}_{3 t 0}^{-}$can be calculated from the sum of residual substrate and accumulated products (Böhlke, 2002). Thus, $c \mathrm{NO}_{3}-\mathrm{N}_{t 0}$ is given by the following equation:

$c \mathrm{NO}_{3}-\mathrm{N}_{\mathrm{t} 0}=\operatorname{excess} \mathrm{N}_{2}+c \mathrm{NO}_{3}^{-}-\mathrm{N}+c \mathrm{~N}_{2} \mathrm{O}-\mathrm{N}$

Reaction progress (RP) is the ratio between products and starting material of a process and can be used to characterize the extent of $\mathrm{NO}_{3}^{-}$elimination by denitrification (Böhlke, 2002). RP is calculated as follows:

$\mathrm{RP}=\frac{\text { excess } \mathrm{N}_{2}+c \mathrm{~N}_{2} \mathrm{O}-\mathrm{N}}{c \mathrm{NO}_{3}-\mathrm{N}_{\mathrm{t} 0}}$

Emission factors (EF) for indirect $\mathrm{N}_{2} \mathrm{O}$ emission from the aquifer resulting from $\mathrm{N}$-leaching were calculated as described earlier (Well et al., 2005a). Because $c \mathrm{NO}_{3 t 0}^{-}$represents the $\mathrm{N}$-input to the aquifer via leaching, our data set is suitable to calculate an $\mathrm{EF}(1)$ from the relationship between potential $\mathrm{N}_{2} \mathrm{O}$ emission and $\mathrm{N}$ input, which is the ideal concept of emission factors (see introduction):

$\mathrm{EF}(1)=\frac{c \mathrm{~N}_{2} \mathrm{O}-\mathrm{N}}{c \mathrm{NO}_{3}-\mathrm{N}_{\mathrm{t} 0}}$
Furthermore, we will compare $\mathrm{EF}(1)$ with the ratio of $c \mathrm{~N}_{2} \mathrm{O}$ $\mathrm{N}$ to $c \mathrm{NO}_{3}^{-}-\mathrm{N}(\mathrm{EF}(2))$, which was used by the IPPC methodology (1997) to derive EF5-g:

$\mathrm{EF}(2)=\frac{c \mathrm{~N}_{2} \mathrm{O}-\mathrm{N}}{c \mathrm{NO}_{3}-\mathrm{N}}$

This concept was frequently used in recent studies to characterize indirect emissions in agricultural drainage water or groundwater (Reay et al., 2003; Sawamoto et al., 2005;) but it is non-ideal, because it assumes that these aquatic systems act solely as a domain of transport without any processing of $\mathrm{NO}_{3}^{-}$and $\mathrm{N}_{2} \mathrm{O}$ (Well et al. 2005a, see introduction). The comparison between $\mathrm{EF}(1)$ and $\mathrm{EF}(2)$ will demonstrate potential errors in predicting indirect $\mathrm{N}_{2} \mathrm{O}$ emission from denitrifying aquifers using $\mathrm{EF}(2)$.

\section{Results}

\subsection{Basic groundwater properties}

Basic groundwater properties of the investigated aquifers are shown in Table 1. Groundwater temperatures at these sites were relatively constant at $10^{\circ} \mathrm{C}$. The $\mathrm{pH}$ and $\mathrm{O}_{2}$ concentrations of the groundwater were more variable, suggesting heterogenous conditions for denitrification and $\mathrm{N}_{2} \mathrm{O}$ accumulation. The ranges of $\mathrm{O}_{2}$ concentrations were similar in all aquifers and demonstrate that the investigated wells included both aerobic and anaerobic zones of each aquifer. Most of the sandy aquifers are acidic (Sulingen, Fuhrberg, Thülsfelde) with similar $\mathrm{pH}$ ranges, whereas $\mathrm{pH}$ of the Göttingen gravel aquifer is close to 7 . 

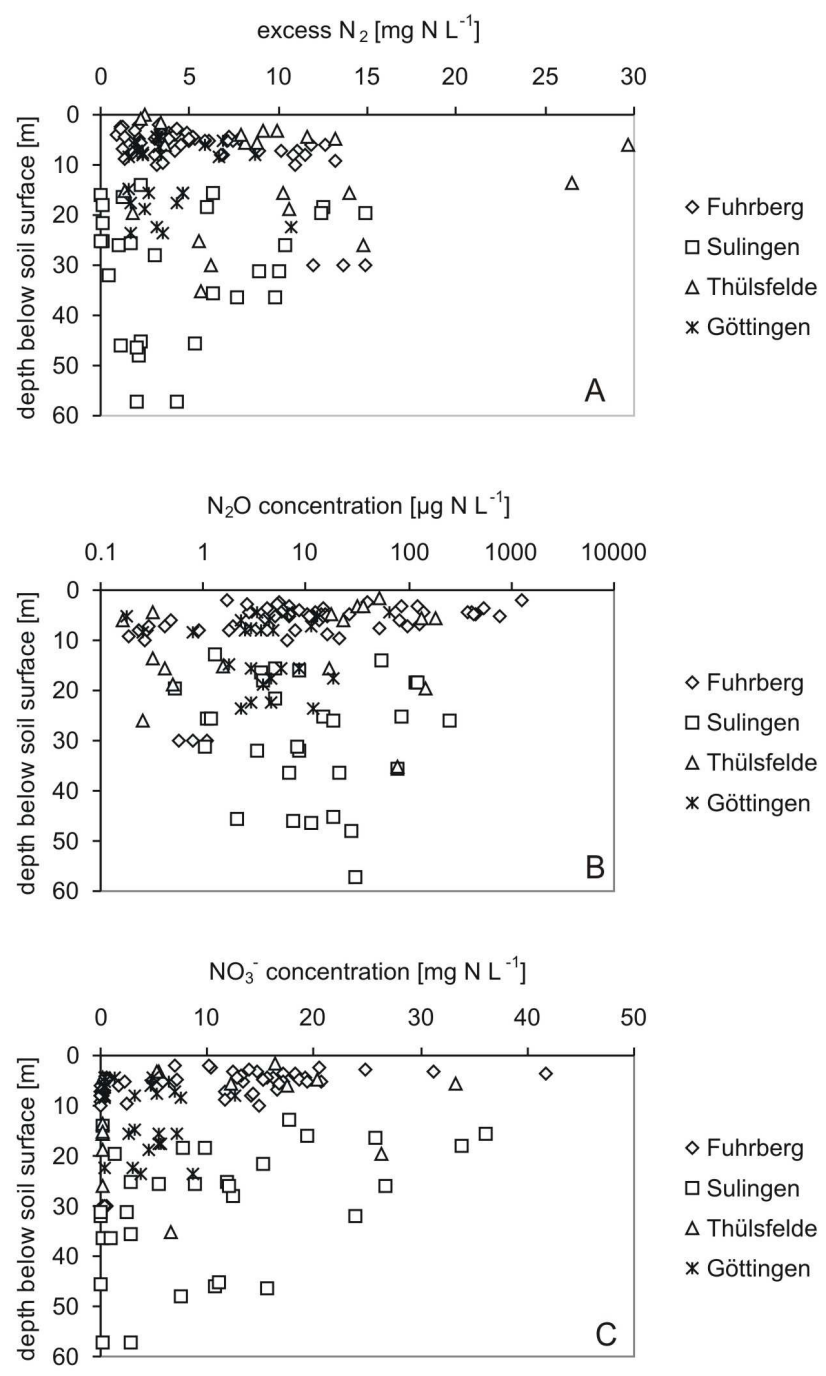

Fig. 1. Vertical distribution of (A) excess $\mathrm{N}_{2}$, (B) $\mathrm{N}_{2} \mathrm{O}$ concentrations (log scaled) and $(\mathbf{C})$ actual $\mathrm{NO}_{3}^{-}$concentrations in the investigated aquifers.

\subsection{Excess $\mathrm{N}_{2}$, measured and initial $\mathrm{NO}_{3}^{-}$concentrations}

We used the means of lowest and upper estimates for excess $\mathrm{N}_{2}$ as a possible best estimate which were calculated assuming complete dissolution or maximum fractionation of entrapped gases, respectively (see Sect. 2.3, Eqs. (2) and (3)). The maximum error is thus half the difference between lowest and upper estimates. The uncertainty connected with this procedure is documented in Fig. 3, where excess $\mathrm{N}_{2}$ min and excess $\mathrm{N}_{2}$ max denote lowest and upper estimates for excess $\mathrm{N}_{2}$, respectively. Derived from the whole data set shown in Fig. 3, the mean difference between lowest and upper estimates for excess $\mathrm{N}_{2}$ is $1.25 \mathrm{mg} \mathrm{N} \mathrm{L}^{-1}$ and the mean of the maximum errors is thus $0.63 \mathrm{mg} \mathrm{NL}^{-1}$ (see Sect. 2.3, Eq. (4)). According to Eq. (5), these error values connected with the uncertainty of excess $\mathrm{N}_{2}$ are also valid for $\mathrm{NO}_{3 t 0}^{-}$.
Using the uncertainty of excess $\mathrm{N}_{2}$ and $\mathrm{NO}_{3 t 0}^{-}$we also estimated the uncertainty of RP (Eq. 6), giving 0.011 for the mean of the maximum errors. From Eq. (7) it follows that the relative error of $\mathrm{EF}(1)$ is equal to the relative error in $\mathrm{NO}_{3 t 0}^{-}$, giving $4.8 \%$ for the median $\mathrm{NO}_{3 t 0}^{-}$of $13.15 \mathrm{mg} \mathrm{N} \mathrm{L}^{-1}$.

Ranges and site medians of excess $\mathrm{N}_{2}$ and reaction progress are given in Table 2. Lowest values for excess $\mathrm{N}_{2}$ coincided with RP of approximately 0 . A RP of approximately 1 was characterized by high values of excess $\mathrm{N}_{2}$ in all aquifers. In all aquifers, samples cover almost the complete range of RP. Highest excess $\mathrm{N}_{2}$ values were observed at Thülsfelde, which were twice the values of the other sites (Fig. 1). At a drinking water well of the Fuhrberg catchment, $\mathrm{NO}_{3}^{-}$and $\mathrm{N}_{2} \mathrm{O}$ concentrations were negligible and excess $\mathrm{N}_{2}$ was $12.9 \mathrm{mg} \mathrm{N} \mathrm{L}^{-1}$ in groundwater samples from a depth of $30 \mathrm{~m}$, which results in RP of 1 . This shows that denitrification is complete in those deeper parts of the Fuhrberg aquifer.

Measured $\mathrm{NO}_{3}^{-}$concentrations were highest in the aquifers of Fuhrberg and Sulingen (Fig. 1) with median values of 8.51 and $9.26 \mathrm{mg} \mathrm{NL}^{-1}$, respectively (Table 2). In Thülsfelde and Göttingen measured $\mathrm{NO}_{3}^{-}$concentrations were significantly lower (Table 2, Fig. 1). We observed the clear tendency that measured $\mathrm{NO}_{3}^{-}$concentrations decreased with increasing sampling depth (Fig. 1c). Calculated initial $\mathrm{NO}_{3}^{-}$concentrations $\left(\mathrm{NO}_{3 t 0}^{-}\right.$, Eq. 5) were substantially higher than measured $\mathrm{NO}_{3}^{-}$concentrations (Table 2), especially in the aquifer of Thülsfelde. The difference between measured $\mathrm{NO}_{3}^{-}$concentrations and $\mathrm{NO}_{3 t 0}^{-}$demonstrates that $\mathrm{NO}_{3}^{-}$consumption by denitrification was an important process in all investigated aquifers.

\section{3 $\quad \mathrm{N}_{2} \mathrm{O}$ concentrations and emission factors}

Wide ranges of $\mathrm{N}_{2} \mathrm{O}$ concentrations were observed in all aquifers (Fig. 1b, Table 2). Highest concentrations up to $1271 \mu \mathrm{g} \mathrm{N}_{2} \mathrm{O}-\mathrm{N} \mathrm{L}^{-1}$ were measured in shallow groundwater at the Fuhrberg site at a RP of 0.35 (Fig. 2).

Emission factors $\mathrm{EF}(1)$ and $\mathrm{EF}(2)$ were highly variable within each site (Table 3). Their medians for the complete data set were 0.00081 and 0.0031 , respectively. Thus, $\mathrm{EF}(2)$ was in agreement with the 2006 IPCC default value for the EF5-g (IPCC, 2006), which was defined as 0.0025 . In contrast, $\mathrm{EF}(1)$ was significantly lower than the 2006 IPCC default value. For the whole data set, $\operatorname{EF}(2)$ was higher than $\mathrm{EF}(1)$. A comparison between $\mathrm{EF}(1)$ and $\mathrm{EF}(2)$ depending on RP is illustrated in Fig. 4. It can be seen that the difference between the emission factors is relatively small if RP is low. With increasing RP, the difference between $\mathrm{EF}(1)$ and $\mathrm{EF}(2)$ is also increasing, resulting in substantial discrepancies at RP close to 1 . Among the sites, median values for each emission factor covered approximately one order of magnitude $(\mathrm{EF}(1)$ : 0.00043 to $0.00438, \mathrm{EF}(2)$ : 0.00092 to 0.01801 ) (Table 3). For both emission factors, we determined highest values for the Fuhrberg aquifer and lowest for the aquifer of Göttingen 

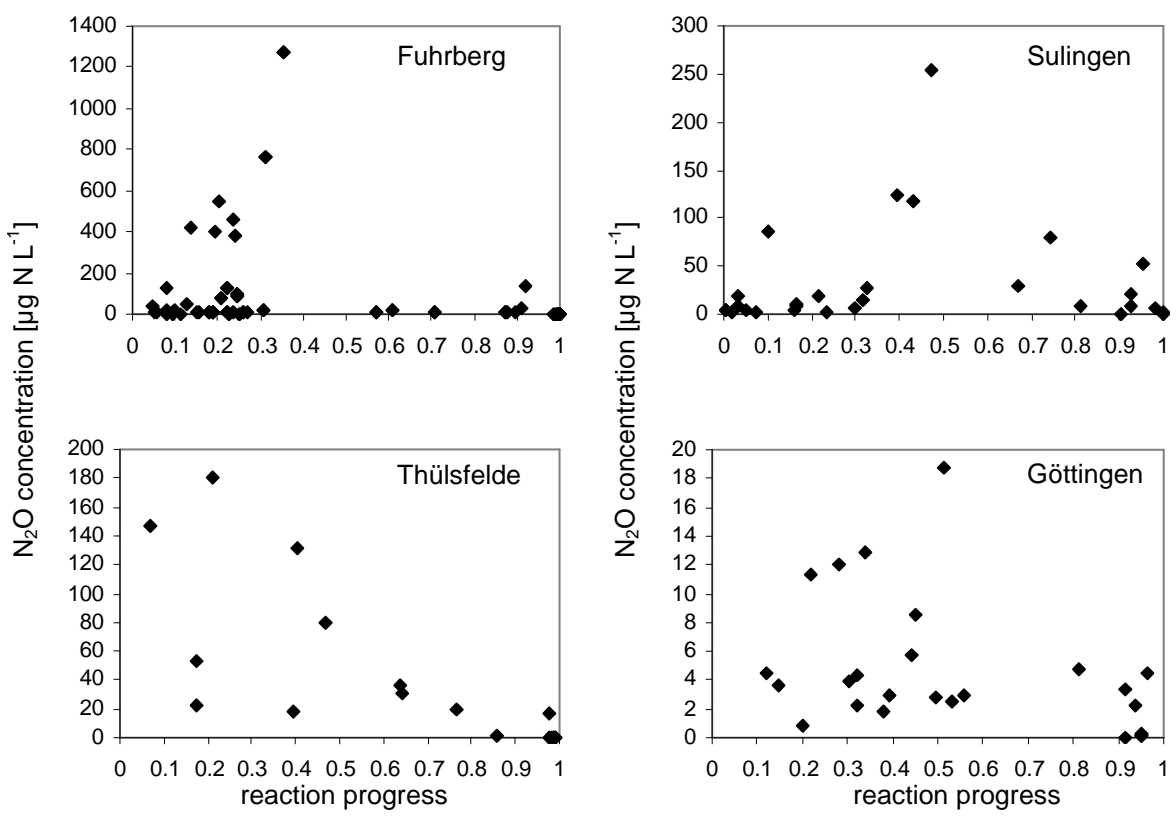

Fig. 2. $\mathrm{N}_{2} \mathrm{O}$ in groundwater samples from 4 different aquifers in relation to reaction progress. Reaction progress is the ratio between denitrification products (excess $\mathrm{N}_{2}+\mathrm{N}_{2} \mathrm{O}$ ) and initial $\mathrm{NO}_{3}^{-}$.

Table 3. Emission factors $\mathrm{EF}(1)$ and $\mathrm{EF}(2)$ of the investigated aquifers. $\mathrm{EF}(1)$ was determined as the ratio of $\mathrm{N}_{2} \mathrm{O} / \mathrm{NO}_{3 t 0}^{-}$concentrations with $\mathrm{NO}_{3 t 0}^{-}$as initial $\mathrm{NO}_{3}^{-}$concentration. $\mathrm{EF}(2)$ was determined as the ratio of $\mathrm{N}_{2} \mathrm{O} / \mathrm{NO}_{3}^{-}$concentrations with $\mathrm{NO}_{3}^{-}$as measured $\mathrm{NO}_{3}^{-}$ concentration.

\begin{tabular}{|c|c|c|c|c|c|c|c|c|}
\hline & \multicolumn{4}{|c|}{$\mathrm{EF}(1)$} & \multicolumn{4}{|c|}{$\mathrm{EF}(2)$} \\
\hline & $\min -\max$ & stand. dev. & mean values & median & $\min -\max$ & stand. dev. & mean values & median \\
\hline Fuhrberg & $0.00004-0.11834$ & 0.0196 & 0.01065 & 0.00438 & $0.00005-0.23971$ & 0.0409 & 0.02382 & 0.01801 \\
\hline Sulingen & $0.00004-0.03816$ & 0.0078 & 0.00380 & 0.00060 & $0.00007-0.51012$ & 0.1225 & 0.04761 & 0.00248 \\
\hline Thülsfelde & $0.00001-0.00643$ & 0.0022 & 0.00194 & 0.00103 & $0.00071-0.07364$ & 0.0167 & 0.00808 & 0.00366 \\
\hline Göttingen & $0.00001-0.01197$ & 0.0005 & 0.00058 & 0.00043 & $0.00011-0.01038$ & 0.0029 & 0.00210 & 0.00092 \\
\hline
\end{tabular}

stand. dev.: standard deviation

(Table 3). For the Fuhrberg and the Sulingen sites, we found $\mathrm{EF}(1)$ median values which are close to the 2006 IPCC default value of 0.0025 . In contrast, we determined significant lower EFs(1) for the aquifers of Thülsfelde and Göttingen.

$\mathrm{N}_{2} \mathrm{O}$ concentrations and $\mathrm{EF}(1)$ followed a rough pattern during RP. Values were lowest at the beginning (RP close to 0 ) and at the end (RP close to 1) of the denitrification process. At a $\mathrm{RP}$ close to $1, \mathrm{~N}_{2} \mathrm{O}$ concentrations were still slightly above the ambient level, despite $\mathrm{NO}_{3}^{-}$was completely consumed. It can be concluded that $\mathrm{EF}(1)$ and $\mathrm{EF}(2)$ would approach zero if $\mathrm{N}_{2} \mathrm{O}$ is completely reduced to $\mathrm{N}_{2}$. In contrast to the lowest values for $\mathrm{N}_{2} \mathrm{O}$ concentrations and $\mathrm{EF}(1)$ at $\mathrm{RP}$ close to 0 and close to $1, \mathrm{~N}_{2} \mathrm{O}$ concentrations and $\mathrm{EF}(1)$ were relatively high at a RP between 0.2 and 0.6 (Figs. 2 and 4). However, at each RP we observed a relatively wide range of $\mathrm{N}_{2} \mathrm{O}$ concentrations and $\mathrm{EF}(1)$.

\section{Discussion}

4.1 Uncertainty of excess $\mathrm{N}_{2}$ estimates and excess $\mathrm{N}_{2}$ related parameters

A certain amount of excess air, i.e. dissolved gas components in excess to equilibrium originating from entrapment of air bubbles at the groundwater surface during recharge (see Sect. 2.3), is often found in aquifers (Green et al., 2007). Heaton et al. (1983) found for their data set excess air concentrations between 3.0 and $26.6 \mathrm{ml} \mathrm{L}^{-1}$. In our study, excess air concentrations were lower and ranged between 0 and $7.5 \mathrm{ml} \mathrm{L}^{-1}$. Although Heaton and Vogel (1981) and Heaton et al. (1983) assumed total dissolution of entrapped gas bubbles for their data set, fractionation of excess air (that means partial solution of the bubbles) is a probable phenomenon 


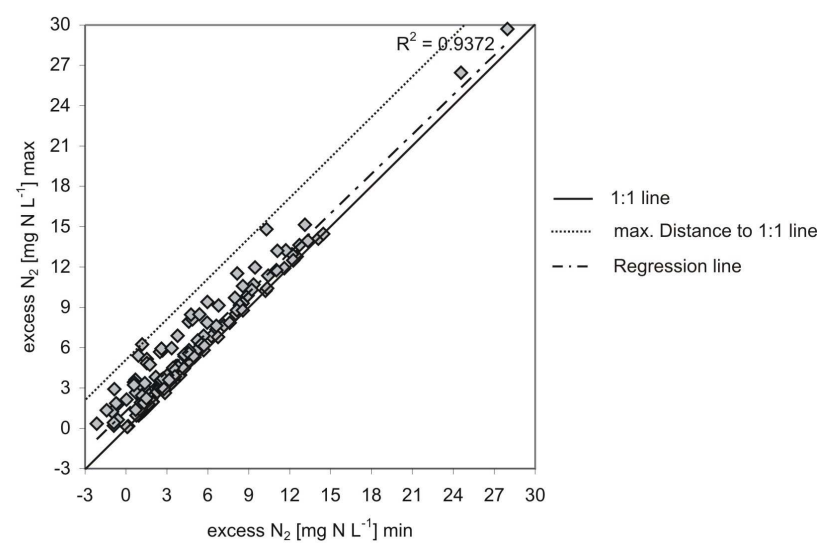

Fig. 3. Lowest (excess $\mathrm{N}_{2} \min$ ) and upper (excess $\mathrm{N}_{2} \max$ ) estimates of excess $\mathrm{N}_{2}$ for the whole data set as calculated using eqs. (1) and (2) or (1) and (3), respectively. The maximum distance to the 1:1 line denotes the maximum difference between the lowest and upper estimates. The regression line refers to the mean of the lowest and upper estimates for the whole data set.

(see Sect. 2.3). This was clearly shown by Aeschbach-Hertig et al. (2002) for different aquifers and different environmental conditions. The extent of fractionation of excess air could not be assessed in our data set, because this requires analysing of several noble gases, what was not done in this study. According to this issue, an uncertainty of excess $\mathrm{N}_{2}$ and of the related parameters was specified in Sects. 2.3 and 3.2.

The uncertainty of RP is small and does not affect our conclusion that maximum $\mathrm{N}_{2} \mathrm{O}$ concentrations occurred at $\mathrm{RP}$ between 0.2 and 0.6 . Thus, this uncertainty hardly affects the relationship between RP and $\mathrm{EF}(1)$ shown in Fig. 4. In view of the large range of $\mathrm{EF}(1)$ (Table 3), the relative error of $\mathrm{EF}(1)$ connected with the uncertainty of $\mathrm{NO}_{3 t 0}^{-}$is relatively small. Therefore, it can be concluded that the consequences of uncertainties connected with excess $\mathrm{N}_{2}$ and $\mathrm{NO}_{3 t 0}^{-}$are negligible for our concept of $\mathrm{EF}(1)$.

Significant degassing of groundwater may occur when the sum of partial pressures of dissolved gases (e.g. Ar, $\mathrm{N}_{2}, \mathrm{O}_{2}$, $\mathrm{CO}_{2}$, and $\mathrm{CH}_{4}$ ) exceeds that of the hydrostatic pressure. This phenomenon was found when high denitrifying activity induced production of excess $\mathrm{N}_{2}$ in shallow groundwater of riparian ecosystems under the presence of low hydrostatic pressure (Blicher-Mathiesen et al., 1998; Mookherji et al., 2003). In our study, these conditions have not been observed. The sum of partial pressures never exceeded hydrostatic pressure which is due to the fact, that the majority of data originates from deeper groundwater where hydrostatic pressure is higher than in shallow groundwater. These conditions prevent degassing of gaseous denitrification products. Unlike the observations of Blicher-Mathiesen et al. (1998) and Mookherji et al. (2003) excess $\mathrm{N}_{2}$ in the shallow groundwater measured in this study was low. This shows that hy-

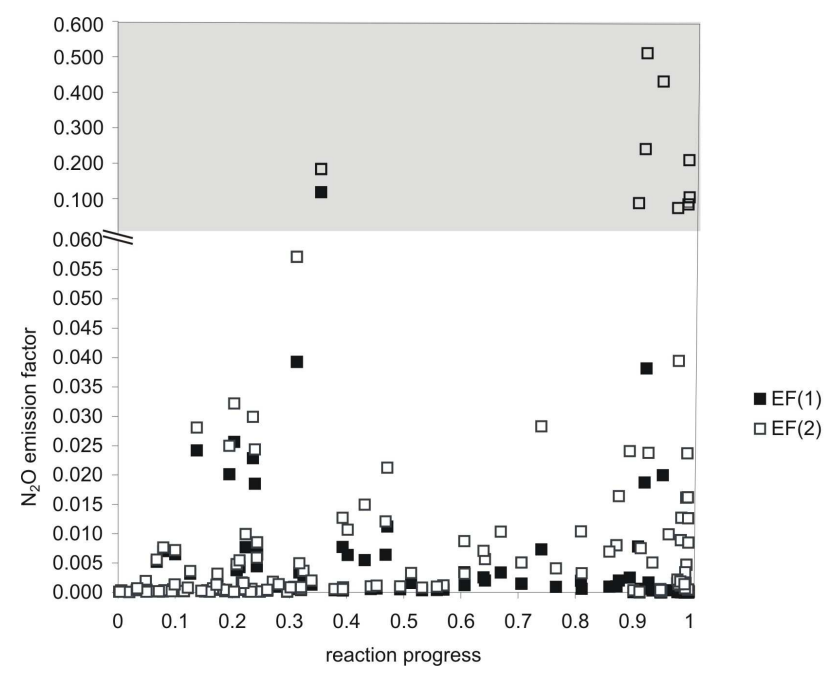

Fig. 4. $\mathrm{N}_{2} \mathrm{O}$ emission factors $\mathrm{EF}(1)$ and $\mathrm{EF}(2)$ of the investigated aquifers in relation to reaction progress (ratio between denitrification products and initial $\mathrm{NO}_{3}^{-}$) and compared to IPCC default EF5g. $\mathrm{EF}(1)$ was determined as the ratio of $\mathrm{N}_{2} \mathrm{O}-\mathrm{N} / \mathrm{NO}_{3}^{-}-\mathrm{N}_{t 0}$ with $\mathrm{NO}_{3}^{-}-\mathrm{N}_{t 0}$ as initial $\mathrm{NO}_{3}^{-}$concentration. $\mathrm{EF}(2)$ was determined as the ratio of $\mathrm{N}_{2} \mathrm{O}-\mathrm{N} / \mathrm{NO}_{3}^{-}-\mathrm{N}$ with $\mathrm{NO}_{3}^{-}-\mathrm{N}$ as actual $\mathrm{NO}_{3}^{-}$concentration.

drostatic pressure was not exceeded by accumulation of dissolved gases and that degassing did not occur. Similar observations for comparable conditions were reported previously (Heaton et al., 1983; Dunkle et al., 1993, Böhlke et al., 1995).

\subsection{Regulating factors of denitrification and $\mathrm{N}_{2} \mathrm{O}$ accumu-} lation

Information on the process dynamics in the investigated aquifers can be obtained from the relationships between parameters of denitrification and $\mathrm{N}_{2} \mathrm{O}$ accumulation and their regulating factors. Within the whole data set, sampling depth exhibited significant positive correlations with RP and significant negative correlations with $\mathrm{NO}_{3}^{-}$(Table 4). Because groundwater residence time generally increases with depth in the upper part of unconfined aquifers, these relationships can be interpreted as a result of ongoing denitrification progress during aquifer passage (Konrad et al., 2007). These relationships and additional significant positive correlations between sampling depth and excess $\mathrm{N}_{2}$ were mostly pronounced in the data-set of Fuhrberg, whereas the correlations were lower or insignificant for the other aquifers (data not shown). The latter suggests that spatial distribution of denitrification within these aquifers was more heterogeneous. In agreement with the results of Vogel et al. (1981) and Konrad (2007), a significant negative correlation between $\mathrm{NO}_{3}^{-}$and excess $\mathrm{N}_{2}$ in the whole data-set $\left(R_{S}=-0.37\right.$, Table 4$)$ demonstrates that denitrification was an important factor for $\mathrm{NO}_{3}^{-}$variability within all aquifers. 
Table 4. Spearman rank correlation coefficients between all variables for the full data-set.

\begin{tabular}{llllllllll}
\hline & depth & $\mathrm{N}_{2} \mathrm{O}$ & $\mathrm{NO}_{3}^{-}$ & excess $\mathrm{N}_{2}$ & $\mathrm{NO}_{3 t 0}^{-}$ & $\mathrm{RP}$ & $\mathrm{EF}(1)$ & $\mathrm{EF}(2)$ & $\mathrm{pH}$ \\
\hline $\mathrm{N}_{2} \mathrm{O}$ & $-0.02 \mathrm{~ns}$ & & & & & & & & \\
$\mathrm{NO}_{3}$ & $-0.29^{* * *}$ & $0.43^{* * *}$ & & & & & & & \\
excess $\mathrm{N}_{2}$ & $0.13 \mathrm{~ns}$ & $-0.19^{*}$ & $-0.37^{* * *}$ & & & & & & \\
$\mathrm{NO}_{3 t 0}^{-}$ & $-0.22^{* *}$ & $0.25^{* *}$ & $0.76^{* * *}$ & $0.18 \mathrm{~ns}$ & & & & & \\
$\mathrm{RP}$ & $0.25^{* * *}$ & $-0.39^{* * *}$ & $-0.86^{* * *}$ & $0.74^{* * *}$ & $-0.43^{* * *}$ & & & & \\
$\mathrm{EF}(1)$ & $-0.03 \mathrm{~ns}$ & $0.93^{* * *}$ & $0.19^{* *}$ & $-0.28^{* * *}$ & $-0.08 \mathrm{~ns}$ & $-0.28^{* * *}$ & & & \\
$\mathrm{EF}(2)$ & $0.16^{*}$ & $0.48^{* * *}$ & $-0.50^{* * *}$ & $0.27^{* * *}$ & $-0.34^{* * *}$ & $0.48^{* * *}$ & $0.62^{* * *}$ & & \\
$\mathrm{pH}$ & -0.04 & $-0.25^{* *}$ & $-0.52^{* * *}$ & $0.37^{* * *}$ & $-0.36^{* * *}$ & $0.57^{* * *}$ & $-0.14 \mathrm{~ns}$ & $0.25^{* *}$ & \\
$\mathrm{O}_{2}$ & $0.16^{*}$ & $-0.05 \mathrm{~ns}$ & $0.21^{* *}$ & $-0.34^{* * *}$ & $0.03 \mathrm{~ns}$ & $-0.34^{* * *}$ & $-0.07 \mathrm{~ns}$ & $-0.42^{* * *}$ & $0.01 \mathrm{~ns}$ \\
\hline
\end{tabular}

RP: reaction progress of denitrification.

* Correlation significant at the 0.05 probability level.

** Correlation significant at the 0.01 probability level.

*** Correlation significant at the 0.001 probability level.

ns: not significant.

$\mathrm{NO}_{3}^{-}$usually inhibits $\mathrm{N}_{2} \mathrm{O}$ reduction to $\mathrm{N}_{2}$ (Blackmer and Bremner, 1978; Cho and Mills, 1979). This is confirmed by the positive correlation between $\mathrm{N}_{2} \mathrm{O}$ and $\mathrm{NO}_{3}^{-}$we found in this study (Table 4). A significant negative correlation was found between $\mathrm{N}_{2} \mathrm{O}$ and $\mathrm{pH}$, which was mostly pronounced in the aquifer with the widest $\mathrm{pH}$ range (Fuhrberg, see Table 1, spearman correlation coefficient $\left.\left(R_{S}\right)=-0.33\right)$. Stevens et al. (1998) emphasized that $\mathrm{pH}$ strongly influences processes that generate $\mathrm{N}_{2} \mathrm{O}$ and $\mathrm{N}_{2} . \mathrm{N}_{2} \mathrm{O}$ accumulation in aquifers might be supported by increasing groundwater acidity because the reduction step of $\mathrm{N}_{2} \mathrm{O}$ to $\mathrm{N}_{2}$ is much more sensitive to acidic conditions compared to the preceding reduction steps (Granli and Bøckman, 1994; BlicherMathiesen and Hoffmann, 1999). The influence of $\mathrm{pH}$ on the $\mathrm{N}_{2} \mathrm{O}$-to- $\mathrm{N}_{2}$ ratio is intensified by high $\mathrm{NO}_{3}^{-}$concentrations (Blackmer and Bremner, 1978; Firestone et al., 1980). Due to these observations we conclude that conditions were especially favourable for $\mathrm{N}_{2} \mathrm{O}$ accumulation and potential $\mathrm{N}_{2} \mathrm{O}$ emission in shallow groundwater of the Fuhrberg aquifer, because it is characterized by high $\mathrm{NO}_{3}^{-}$contamination and comparatively low $\mathrm{pH}$. This is confirmed by our data since $\mathrm{N}_{2} \mathrm{O}$ concentrations of these samples were highest within the entire data-set.

4.3 Potential indirect $\mathrm{N}_{2} \mathrm{O}$ emissions from groundwater estimated from initial $\mathrm{NO}_{3}^{-}$concentration

Unlike emission factors determined from measured fluxes across the soil surface, emission factors estimated from groundwater concentration do not reflect the actual $\mathrm{N}_{2} \mathrm{O}$ emission from the system because the amount of dissolved $\mathrm{N}_{2} \mathrm{O}$ might increase or decrease during further residence time in the aquifer or during the passage of the unsaturated zone before it reaches the atmosphere (Höll et al., 2005; Well et al., 2005a). These dynamics of $\mathrm{N}_{2} \mathrm{O}$ in groundwater are complex and variable and should be considered in the development of improved inventory calculations (Clough et al., 2007). Moreover, diffusive $\mathrm{N}_{2} \mathrm{O}$ emission from the aquifer surface to the unsaturated zone and eventually to the atmosphere (Deurer et al., 2008) is not taken into account by $\mathrm{EF}(1)$. Therefore, the measured data supply only potential emission factors quantifying the amount of $\mathrm{N}_{2} \mathrm{O}$ which could be emitted, if the groundwater was immediately discharged to springs, wells or streams. The determination of an effective emission factor to quantify real $\mathrm{N}_{2} \mathrm{O}$ flux from the investigated aquifers requires validated models of reactive $\mathrm{N}_{2} \mathrm{O}$ transport. Further research on reaction dynamics and gas transport within the aquifers is needed to achieve this.

However, the comparison of $\mathrm{N}_{2} \mathrm{O}$ concentration and $\mathrm{EF}(1)$ with RP gives a rough sketch of the principal $\mathrm{N}_{2} \mathrm{O}$ pattern during groundwater transport through denitrifying aquifers. Although variations of $\mathrm{N}_{2} \mathrm{O}$ and $\mathrm{EF}(1)$ at any given level of $\mathrm{RP}$ were high, there was a clear tendency of low $\mathrm{N}_{2} \mathrm{O}$ concentrations for RP close to zero or close to 1 and highest $\mathrm{N}_{2} \mathrm{O}$ concentrations at RP between 0.2 and 0.6. This pattern is consistent with the time course of $\mathrm{N}_{2} \mathrm{O}$ during complete denitrification in closed systems observed by modelling (Almeida et al., 1997) as well as laboratory incubations (Well et al., 2005b) and can be explained by the balance between production and reduction of $\mathrm{N}_{2} \mathrm{O}$ during a Michaelis-Menten reaction kinetics. It can be concluded that $\mathrm{RP}$ can be considered as an important parameter to predict $\mathrm{N}_{2} \mathrm{O}$ emission via groundwater discharge. This emission can be expected to be negligible if RP at groundwater discharge is very small or close to 1 . However, the occurrence of individual samples with comparatively high $\mathrm{N}_{2} \mathrm{O}$ concentrations at RP close to 0 (Fig. 2, Thülsfelde) indicates that the RP range that covers the highest $\mathrm{N}_{2} \mathrm{O}$ concentrations might be even more variable. Conversely, relatively high emission can be expected if RP at groundwater discharge is between 0.2 and 0.6 . The observed 
relationships suggest that emission factors are also related to denitrification rate, groundwater residence time and sampling depth because these quantities determine the reaction progress (Konrad, 2007). This could be helpful to predict or interpret $\mathrm{N}_{2} \mathrm{O}$ emission from different types of groundwater systems. For example, low $\mathrm{N}_{2} \mathrm{O}$ fluxes observed from tile drainage outlets (Reay et al., 2003) might be explained by relatively low groundwater residence time of this drainage system. The deep wells of the investigated aquifers with low residual $\mathrm{NO}_{3}^{-}$and low $\mathrm{N}_{2} \mathrm{O}$ concentration reflect the typical low emission factors at RP close to 1 . Hot spots of $\mathrm{N}_{2} \mathrm{O}$ emission from groundwater might be locations were groundwater is discharged to surface waters immediately after partial $\mathrm{NO}_{3}^{-}$consumption which is known to occur after the subsurface flow through riparian buffers (Hefting et al., 2003).

A downward revision of the EF5-g default value by the IPCC from 0.015 (1997) to 0.0025 (2006) was based on recent findings of Hiscock et al. (2002, 2003), Sawamoto et al. (2005) and Reay et al. (2005). This is supported by site medians of $\mathrm{EF}(1)$ of this study (Table 3 ) which scatter around the revised EF5-g. Obviously, the former 1997 IPCC EF5$\mathrm{g}$ default value of 0.015 substantially overestimated indirect $\mathrm{N}_{2} \mathrm{O}$ emissions from groundwater. A comparison of the emission factors $\mathrm{EF}(1)$ and $\mathrm{EF}(2)$ clearly shows lower values for $\mathrm{EF}(1)$ which results from the consideration of initial $\mathrm{NO}_{3}^{-}$ by $\mathrm{EF}(1)$. The deviation between $\mathrm{EF}(1)$ and $\mathrm{EF}(2)$ is highly relevant in aquifers with substantial denitrifying activity and high $\mathrm{N}$ inputs like those investigated in this study. Furthermore, Fig. 4 demonstrates that differences between $\mathrm{EF}(1)$ and $\mathrm{EF}(2)$ are increasing with reaction progress of denitrification. This clearly demonstrates that it is important to take the dynamic turnover of $\mathrm{NO}_{3}^{-}$during groundwater passage into account. This is also confirmed by Hiscock et al. (2003). The authors stated that future studies are needed which take into account denitrification losses to refine $\mathrm{N}_{2} \mathrm{O}$ budgets further. Consequently, potential $\mathrm{N}_{2} \mathrm{O}$ emissions from aquifers should be estimated using $\mathrm{EF}(1)$ rather than $\mathrm{EF}(2)$.

\section{Conclusions}

In the investigated aquifers, $\mathrm{NO}_{3}^{-}$consumption by denitrification was estimated from excess $\mathrm{N}_{2}$ as determined from dissolved $\mathrm{N}_{2}$ and Ar. This enabled calculation of initial $\mathrm{NO}_{3}^{-}$ concentration at the groundwater surface by adding up concentrations of $\mathrm{NO}_{3}^{-}, \mathrm{N}_{2} \mathrm{O}$ and excess $\mathrm{N}_{2}$. Ranges of $\mathrm{N}_{2} \mathrm{O}$ concentrations in groundwater were large in all aquifers, covering an interval between 0 and $1271 \mu \mathrm{g} \mathrm{N} \mathrm{L}^{-1}$. The $\mathrm{pH}$ was found to be a significant controlling factor for $\mathrm{N}_{2} \mathrm{O}$ accumulation. Because initial $\mathrm{NO}_{3}^{-}$concentration reflects the $\mathrm{N}$ input to the groundwater by leaching, it was used to calculate an emission factor $\mathrm{EF}(1)$ for indirect agricultural $\mathrm{N}_{2} \mathrm{O}$ emissions from groundwater which is for the first time based on the ratio between $\mathrm{N}_{2} \mathrm{O}$ concentration and $\mathrm{N}$-input. An uncertainty of excess $\mathrm{N}_{2}$ estimates according to the excess air phenomenon was found to be negligible for this concept of $\mathrm{EF}(1) . \mathrm{EF}(1)$ in the investigated denitrifying aquifers was much lower than the values resulting from the earlier concept of groundwater emission factors consisting of $\mathrm{N}_{2} \mathrm{O}$-to- $\mathrm{NO}_{3}^{-}$ mass ratios of groundwater samples $(\mathrm{EF}(2)$ in this study). This demonstrates the need to take past $\mathrm{NO}_{3}^{-}$consumption into account when determining groundwater emission factors. In agreement with recent literature data our observations support the substantial downward revision of the IPCC default EF5-g from 0.015 (1997) to 0.0025 (2006). However, there are still uncertainties with respect to a single emission factor for the effective $\mathrm{N}_{2} \mathrm{O}$ flux from the investigated aquifers because spatial und temporal heterogeneity of $\mathrm{N}_{2} \mathrm{O}$ concentrations was high and further metabolism of $\mathrm{N}_{2} \mathrm{O}$ during transport in the aquifer and through the unsaturated zone before it is emitted is poorly understood.

Acknowledgements. This study was funded by the German Research Foundation (DFG). We gratefully acknowledge the cooperation with Wasserverband Sulinger Land, OldenburgischOstfriesischer Wasserverband, Stadtwerke Göttingen, and Stadtwerke Hannover. We thank Ingrid Ostermeyer and Antje Keitel for technical assistance.

Edited by: M. Dai

\section{References}

Aeschbach-Hertig, W., Beyerle, U., Holocher, J., Peeters, F., and Kipfer, R.: Excess air in groundwater as a potential indicator of past environmental changes, in: Study of Environmental Change using Isotope Techniques, IAEA, Vienna, Austria, C\&S Papers Series 13/P, 174-183, 2002.

Almeida, J. S., Reis, M. A. M., and Carrondo M. J. T.: A unifying kinetic model of denitrification, J. Theor. Biol., 186, 241-249, 1997.

Blackmer, A. M. and Bremner, J. M.: Inhibitory effect of nitrate on reduction of nitrous oxide to molecular nitrogen by soil microorganisms, Soil Biol. Biochem., 10, 187-191, 1978.

Blicher-Mathiesen, G., McCarty G. W., and Nielsen, C. P.: Denitrification and degassing in groundwater estimated from dissolved nitrogen and argon, J. Hydrol., 208, 16-24, 1998.

Blicher-Mathiesen, G. and Hoffmann, C. C.: Denitrification as a sink for dissolved nitrous oxide in a freshwater riparian fen, J. Environ. Qual., 28, 257-262, 1999.

Böhlke, J. K.: Groundwater recharge and agricultural contamination, Hydrogeol. J., 10, 153-179, 2002.

Böhlke, J. K. and Denver J. M.: Combined use of groundwater dating, chemical and isotopic analyses to resolve the history and fate of nitrate contamination in two agricultural watersheds, Atlantic Coastal Plain, Maryland, Water Resour. Res., 31, 2319-2339, 1995.

Böttcher, J., Strebel, O., and Duijnisveld, W. H. M.: Vertikale Stoffkonzentrationsprofile im Grundwasser eines Lockergesteins-Aquifers und deren Interpretation (Beispiel Fuhrberger Feld), Z. dt. Geol. Ges., 136, 543-552, 1985.

Böttcher, J., Strebel, O., Voerkelius, S., and Schmidt, H. L.: Using isotope fractionation of nitrate-nitrogen and nitrate-oxygen 
for evaluation of microbial denitrification in a sandy aquifer, $\mathrm{J}$. Hydrol., 114, 413-424, 1990.

Cho, C. M. and Mills, J. G.: Kinetic formulation of the denitrification process in soil, Can. J. Soil. Sci., 59, 249-257, 1979.

Clough, T. J., Sherlock, R. R., and Rolston, D. E.: A review of the movement and fate of $\mathrm{N}_{2} \mathrm{O}$ in the subsoil, Nutr. Cycl. Agroecosys., 72, 3-11, 2005.

Clough, T. J., Addy, K., Kellogg, D. Q., Nowicki, B. L., Gold, A. J., and Groffman, P. M.: Dynamics of nitrous oxide in groundwater at the aquatic-terrestrial interface, Global Change Biol., 13, 1528-1537, 2007.

Crutzen, P. J.: Atmospheric chemical processes of the oxides of nitrogen, including nitrous oxide, in: Denitrification, nitrification and nitrous oxide, edited by: Delwiche, C., Wiley, New York, 17-44, 1981.

Deurer, M., von der Heide, C., Böttcher, J., Duijnisveld, W. H. R., Weymann, D., and Well, R.: The dynamics of $\mathrm{N}_{2} \mathrm{O}$ near the groundwater table and the transfer of $\mathrm{N}_{2} \mathrm{O}$ into the unsaturated zone: A case study from a sandy aquifer in Germany, Catena, 72, 362-373, 2008.

Dobbie, K. E. and Smith, K. A.: Nitrous oxide emission factors for agricultural soils in Great Britain: the impact of soil water-filled pore space and other controlling variables, Global Change Biol., 9, 204-218, 2003.

Dunkle, S. A., Plummer, L. N., Busenberg, E., Phillips, P. J., Denver, J. M., Hamilton, P. A., Michel, R. L., and Coplen, T. B.: Chlorofluorocarbons $\left(\mathrm{CCl}_{3} \mathrm{~F}\right.$ and $\left.\mathrm{CCl}_{2} \mathrm{~F}_{2}\right)$ as dating tools and hydrologic tracers in shallow ground water of the Delmava Peninsula, Atlantic Coastal Plain, United States, Water Resour. Res., 29, 3837-3860, 1993.

Duxbury, J. M. and Mosier, A. R.: Status and issues concerning agricultural emissions of greenhouse gases, in: Agricultural dimensions of global climate change, edited by: Kaiser, H. M. and Drennen, T. E., St. Lucie Press, USA, 229-258, 1993.

Firestone, M. K., Firestone, R. B., and Tiedje, J. M.: Nitrous oxide from soil denitrification: factors controlling its biological production, Science, 208, 749-751, 1980.

Granli, T. and Bøckman, O. C.: Nitrous oxide from agriculture, Norwegian Journal of Agricultural Sciences, 12, 128 pp., 1994.

Green, T. C., Puckett, L. J., Böhlke, J. K., Bekins, B. A., Phillips, S. P., Kauffman, L. J., Denver, J. M., and Johnson, H. M.: Limited occurance of denitrification in four shallow aquifers in agricultural areas of the United States, J. Environ. Qual., 37, 994-1009, doi:10.2134/jeq2006.0419, 2008.

Heaton, T. H. E. and Vogel, J. C.: Excess air in groundwater, J. Hydrol., 50, 201-216, 1981.

Heaton, T. H. E., Talma, A. S., and Vogel, J. C.: Origin and history of nitrate in confined groundwater in the Western Kalahari, J. Hydrol., 62, 243-262, 1983.

Hefting, M. M., Bobbink, R., and de Caluwe, H.: Nitrous oxide emission and denitrification in chronically nitrate-loaded riparian buffer zones, J. Environ. Qual., 32(4), 1194-1203, 2003.

Hiscock, K. M., Bateman, A. S., Fukada, T., and Dennis, P. F.: The concentration and distribution of groundwater $\mathrm{N}_{2} \mathrm{O}$ in the chalk aquifer of eastern England, in: Proceedings 3rd International Symp. on non- $\mathrm{CO}_{2}$ greenhouse gases, edited by: van Ham, J., Baede, A. P. M., Guicherit, R., and Williams-Jacobsen, J. G. F. M., Maastricht, The Netherlands, 185-190, 2002.

Hiscock, K. M., Bateman, A. S., Mühlherr, I. H., Fukada, T., and
Dennis, P. F.: Indirect emissions of nitrous oxide from regional aquifers in the United Kingdom, Environ. Sci. Technol., 37, 3507-3512, 2003.

Holocher, J., Peeters, F., Aeschbach-Hertig, W., Hofer, M., Brennwald, M., Kinzelbach, W., and Kipfer, R.: Experimental investigations on the formation of excess air in quasi-saturated porous media, Geoch. Cosm. Acta, 66, 4103-4117, 2002.

Höll, B. S., Jungkunst, H. F., Fiedler, S., and Stahr, K.: Indirect nitrous oxide emission from a nitrogen saturated spruce forest and general accuracy of the IPCC methodology, Atmos. Environ., 39, 5959-5970, 2005.

Kölle, W., Strebel, O., and Böttcher, J.: Formation of sulfate by microbial denitrification in a reducing aquifer, Water Supply, 3, 35-40, 1985.

International Panel on Climate Change: Revised 1996 IPCC guidelines for national greenhouse gas inventories, Reference manual, Vol. 3, Organisation for Economic Cooperation and Development, Paris, 1997.

International Panel on Climate Change: 2006 IPCC guidelines for national greenhouse gas inventories, Prepared by the National Greenhouse Gas Inventories Programme, edited by: Egglestone H. S., Buendia L., Miwa, K., Ngara T., and Tanabe, K., IGES, Japan, 2006.

Konrad, C.: Methoden zur Bestimmung des Umsatzes von Stickstoff, dargestellt für drei pleistozäne Grundwasserleiter Norddeutschlands, PhD thesis, Dresden Univ. of Techn., Germany, 157 pp., 2007.

McMahon, P. B., Bruce, B. W., Becker, M. F., Pope, L. M., and Dennehy, K. F.: Occurrence of nitrous oxide in the Central High Plains Aquifer, 1999, Environ. Sci. Technol., 34, 4873-4877, 2000.

Mölders, N., Jankov, M., and Kramm, G.: Application of Gaussian error propagation principles for theoretical assessment of model uncertainty in simulated soil processes caused by thermal and hydraulic parameters, J. Hydromet., 6, 1045-1062, 2005.

Mookherji, S., McCarty, G. W., and Angier, J. T.: Dissolved gas analysis for assessing the fate of nitrate in wetlands, J. American Wat. Res. Ass., 39(2), 381-387, 2003.

Mosier, A., Kroeze, C., Nevison, C., Oenema, O., Seitzinger, S., and van Cleemput, O.: Closing the global $\mathrm{N}_{2} \mathrm{O}$ budget: $\mathrm{Ni}-$ trous oxide emissions through the agricultural nitrogen cycle. OECD/IPCC/IEA Phase II: development of IPCC guidelines for national greenhouse gas inventory methodology, Nutr. Cycl. Agroecosys., 52, 225-248, 1998.

Nevison, C.: Review of the IPCC methodology for estimating nitrous oxide emissions associated with agricutural leaching and runoff, Chemosphere, 2, 493-500, 2000.

Pätsch, M.: Analyse des Nitratumsatzes und dessen Heterogenität im quartären Grundwasserleiter des Wasserwerkes Thülsfelde Berücksichtigung bei der Modellierung des Transportes, $\mathrm{PhD}$ thesis, Dresden Univ. of Techn., Germany, 223 pp., 2006.

Reay, D. S., Smith, K. A., and Edwards, A. C.: Nitrous oxide emission from agricultural drainage waters, Global Change Biol., 9, 195-203, 2003.

Reay, D. S., Smith, K. A., Edwards, A. C., Hiscock, K. M., Dong, L. F., and Nedwell, D. B.: Indirect nitrous oxide emissions: revised emission factors, Environ. Sci., 2(2-3), 153-158, 2005.

Ronen, D., Magaritz, M., and Almon, E.: Contaminated aquifers are a forgotten component of the global $\mathrm{N}_{2} \mathrm{O}$ budget, Nature, 
335, 57-59, 1988.

Ross, S. M.: Overview of the hydrochemistry and solute processes in British wetlands, in: Hydrology and hydrochemistry of British wetlands, edited by: Hughes, J. M. R. and Heathwaite, A. L., Wiley, New York, 133-182, 1995.

Sawamoto, T., Nakajima, Y., Kasuya, M., Tsuruta, H., and Yagi, K.: Evaluation of emission factors for indirect $\mathrm{N}_{2} \mathrm{O}$ emission due to nitrogen leaching in agro-ecosystems, Geophys. Res. Let., 32(3), L03403, doi:10.1029/2004GL021625, 2005.

Schlie, P.: Hydrogeologie des Grundwasserwerkes Stegemühle in Göttingen, $\mathrm{PhD}$ thesis, university of Göttingen, Germany, 137 pp., 1989.

Stevens, R. J., Laughlin, R. J., and Malone, J. P.: Soil pH affects the processes reducing nitrate to nitrous oxide and di-nitrogen, Soil Biol. Biochem., 30, 1119-1126, 1998.

Strebel, O., Böttcher J., and Duijnisveld W. H. M.: Ermittlung von Stoffeinträgen und deren Verbleib im Grundwasserleiter eines norddeutschen Wassergewinnungsgebietes, Texte 46/93, Umweltbundesamt, Berlin, 1993.

Vogel, J. C., Talma, A. S., and Heaton, T. H. E.: Gaseous nitrogen as evidence for denitrification in groundwater, J. Hydrol., 50, 191200, 1981.

Walther, W.: Diffuser Stoffeintrag in Böden und Gewässer, Teubner BG, Stuttgart, Germany, 1999.
Walther, W., Pätsch M., Weller D., Reinstorf F., Harms E., and Kersebaum C.: Nutrient loads on a Northern German sandy aquifer, reduction processes, their distribution and management tools, in: New approaches to characterising Groundwater Flow, XXXI, IAH Congress, Munich, Germany, 10-14 September 2001.

Weiss, R. F.: The solubility of nitrogen, oxygen and argon in water and sea water, Deep Sea Res., 17, 721-735, 1970.

Weiss, R. F.: The solubility of helium and neon in water and sea water, J. Chem. Eng. Data, 16, 235-241, 1971.

Weiss, R. F. and Price, B. A.: Nitrous oxide solubility in water and sea water, Mar. Chem., 8, 347-359, 1980.

Well, R. and Myrold, D. D.: Laboratory evaluation of a new method for in situ measurement of denitrification in water-saturated soils, Soil Biol. Biochem., 31, 1109-1119, 1999.

Well, R., Augustin, J., Meyer, K., and Myrold, D.D.: Comparison of field and laboratory measurement of denitrification and $\mathrm{N}_{2} \mathrm{O}$ production in the saturated zone of hydromorphic soils, Soil Biol. Biochem., 35, 783-799, 2003.

Well, R., Weymann, D., and Flessa, H.: Recent research progress on the significance of aquatic systems for indirect agricultural $\mathrm{N}_{2} \mathrm{O}$ emissions, Environ. Sci., 2(2-3), 143-151, 2005a.

Well, R., Flessa, H., Jaradat, F., Toyoda, S., and Yoshida, N.: Measurement of isotopomer signatures of $\mathrm{N}_{2} \mathrm{O}$ in groundwater, J. Geophys. Res.-Bio., 110, G02006, doi:10.1029/2005JG000044, 2005b. 